\title{
To the issue of monitoring the length of degasification boreholes
}

\author{
Gennadii Rout ${ }^{1}$, Oleg Tailakov ${ }^{2 *}$, Denis Zastrelov ${ }^{2}$, Sergey Kolesnichenko ${ }^{2}$ \\ ${ }^{1}$ T.F. Gorbachev Kuzbass State Technical University \\ ${ }^{2}$ The Federal Research Center of Coal and Coal-Chemistry of Siberian Branch of the Russian \\ Academy of Sciences
}

\begin{abstract}
Based on the application of the echolocation method, the length of degassing wells at the coal mine of the Leninsky geological and economic district of Kuzbass, drilled into the coal seam from mining workings, was measured. Recommendations for the effective use of geophysical equipment for monitoring the state of degassing wells in coal mines are justified and formed. The results of measurements of the length of horizontal degassing wells drilled from mine workings, as well as the methane content in them, are presented. Software has been developed to refine the performed measurements of the length of degassing wells, which allows you to quickly determine the length of degassing wells with satisfactory accuracy. The results of the well length processed with the help of the software are presented.
\end{abstract}

\section{Introduction}

Underground coal mining in the Russian Federation is associated with a sharp increase of load on the working face and the increased influence of a gas factor. With the coal mining depth increase the in-situ gas content of coal seams enhances In this regard, the coal seams degasification becomes of great importance. Degasification procedure is carried out on unloaded coal seams and on those that are under mining. The coalbed methane recovery from unloaded coal seams is carried out by drilling vertical and inclined wells from the surface during shafts construction and by directional drilling from banks of workings or into the coal seam while laying out the main workings and workings made in coal seams.

\section{Methodologies}

The coal seams degasification efficiency depends on stability of boreholes that are used for methane recovery $[1,2]$. At the same time, it is necessary to ensure the control of their condition [3-6]. To control coal seams degasification process it is proposed to use the echolocation method, which provides the registration of time interval between generation and arrival of an acoustic signal from the media interface (Figure 1).

\footnotetext{
*Corresponding author: tailakovov@kuzstu.ru
} 


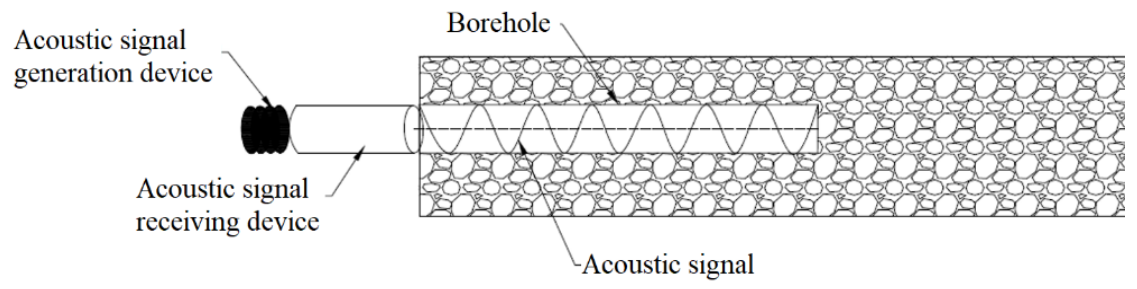

Fig. 1. Schematic representation of the echolocation method.

In mine measurements, a set of equipment was used, that includes a recording unit, a device for generating and receiving an acoustic signal (Figure 2).

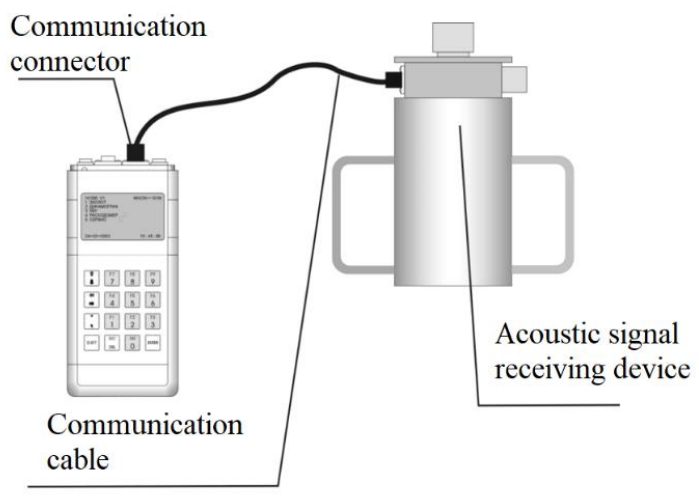

Fig. 2. A set of equipment for length measurements of degas boreholes in mine conditions.

The field stage of degas boreholes length measurement by using the "Echolot" sounder facilities in mine conditions was carried out as follows: initially, boreholes with known parameters are selected, then space availability to carry out the work is examined. After inspecting the borehole accessibility, the concentration of methane, oxygen and temperature at the wellhead are measured. Switching on and testing the equipment is performed after selecting the nozzle and connecting the device for receiving the acoustic signal to the recording unit. Then generation and registration of the acoustic signal is carried out.Cameral work includes preparation, processing, analysis and interpretation of the data obtained. The stage of cameral processing of the recorded data is necessary to improve the accuracy of degas boreholes length measurements, for this, the signal amplitude-frequency characteristics are filtered, the mark of the acoustic signal first reflection is determined, the distance from the wellhead to theborehole bottom is determined, noise and interferences are excluded when receiving an acoustic signal (Figure 3).

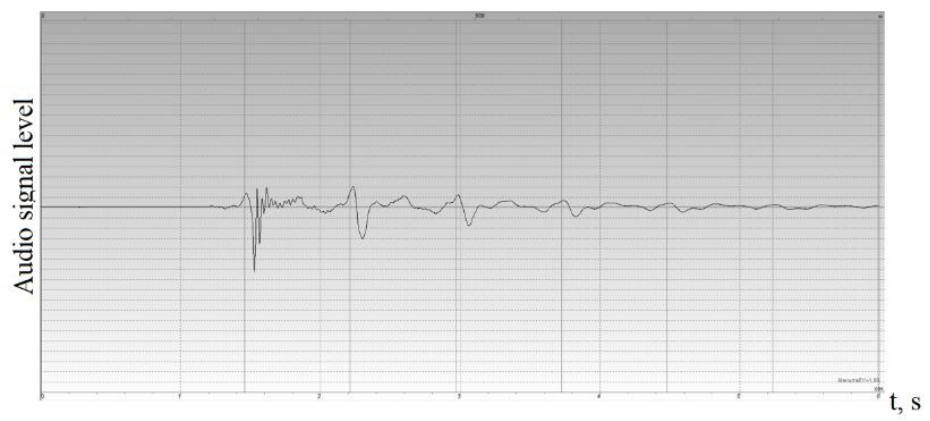


Fig. 3. The resulting echogram of the borehole using the filtering of the amplitude-frequency characteristics and the determined first mark of the reflected acoustic signal.

\section{Results and Discussion}

The results of undertaken length measurements of horizontal degasification borehole drilled from mine workings in one of coal mines of Leninsky geological and economic region of Kuzbass, as well as the methane content in them, are summarized and shown in Table 1.

Table 1.Results of monitoring changes in length and methane concentrations at the wellhead.

\begin{tabular}{|c|c|c|c|c|c|c|c|}
\hline \multirow{2}{*}{ 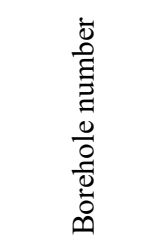 } & \multirow{2}{*}{ 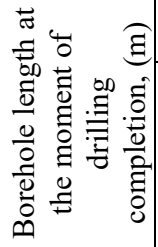 } & \multicolumn{3}{|c|}{ Measurement results } & \multirow{2}{*}{ 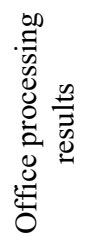 } & \multirow{2}{*}{ 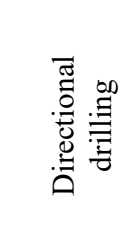 } & \multirow{2}{*}{ 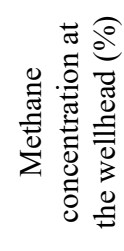 } \\
\hline & & $\begin{array}{c}\text { Measu } \\
\text { remen } \\
\mathrm{t} \text { №1 }\end{array}$ & $\begin{array}{l}\text { Measure } \\
\text { ment№2 }\end{array}$ & $\begin{array}{c}\text { Measure } \\
\text { ment } \\
\text { №3 }\end{array}$ & & & \\
\hline $\begin{array}{l}\text { borehole } \\
\text { №1 }\end{array}$ & 150 & 103 & 103 & 104 & 103 & coal seam & 1.98 \\
\hline $\begin{array}{c}\text { boreholea } \\
\quad № 2\end{array}$ & 150 & 80 & 81 & 81 & 81 & coal seam & 1.98 \\
\hline $\begin{array}{l}\text { borehole } \\
\quad № 3\end{array}$ & 150 & 80 & 79 & 78 & 80 & coal seam & 7 \\
\hline $\begin{array}{c}\text { borehole } \\
\text { №4 }\end{array}$ & 150 & 109 & 110 & 109 & 109 & coal seam & 8 \\
\hline $\begin{array}{l}\text { borehole a } \\
\quad № 5\end{array}$ & 150 & 122 & 122 & 122 & 122 & coal seam & 20.51 \\
\hline $\begin{array}{c}\text { borehole } \\
\text { №6 }\end{array}$ & 150 & 102 & 101 & 102 & 102 & coal seam & 6 \\
\hline $\begin{array}{c}\text { borehole } \\
\text { №7 }\end{array}$ & 150 & 55 & 54 & 56 & 55 & Coal seam & 1.98 \\
\hline $\begin{array}{l}\text { borehole } \\
\text { №8 }\end{array}$ & 150 & 136 & 140 & 134 & 134 & Coal seam & 5 \\
\hline $\begin{array}{c}\text { borehole } \\
\text { №9 }\end{array}$ & 150 & 97 & 92 & 92 & 92 & Coal seam & 8 \\
\hline $\begin{array}{c}\text { borehole } \\
\text { №10 }\end{array}$ & 150 & 74 & 70 & 72 & 70 & Coal seam & 7 \\
\hline
\end{tabular}

The borehole length is determined by the formula:

$$
L=v \cdot t=\sqrt{\frac{\gamma R T}{M}} \cdot t=\alpha \sqrt{T} \cdot t
$$

where $v$ is the speed of the acoustic wave, $\mathrm{m} / \mathrm{s}$; $\mathrm{t}$ is the time of acoustic wave passage, $\mathrm{s} ; \gamma$ is the adiabatic index; $\mathrm{R}$ is the universal gas constant; $\mathrm{T}$ is the absolute temperature, ${ }^{\circ}$ $\mathrm{K} ; \mathrm{M}$ is the molar mass of the gas mixture, $\mathrm{g} / \mathrm{mol} ; \alpha=\sqrt{ }(" \gamma \mathrm{R} " \mathrm{M})[7,8]$.

The formula (1) indicates that a propagation speed of a sound wave depends on the gasair mixture composition, as well as on the temperature. To refine the measurement results, additional software has been developed that allows editing data obtained during results processing [9, 10].The software interface is shown in Figure 4, 5. Data editing is carried out as follows: the obtained results are imported from the registration unit to the PC; after importing data using the developed software, the results are presented in the form of 
ordered data, filtered by time; to edit the results, the operator starts the sound speed editing module, enters the temperature, methane and oxygen content into the program, which were recorded during measurements in mine conditions; the software automatically recalculates the speed of the acoustic wave in the gas-air mixture and provides the result of a degas borehole extent.

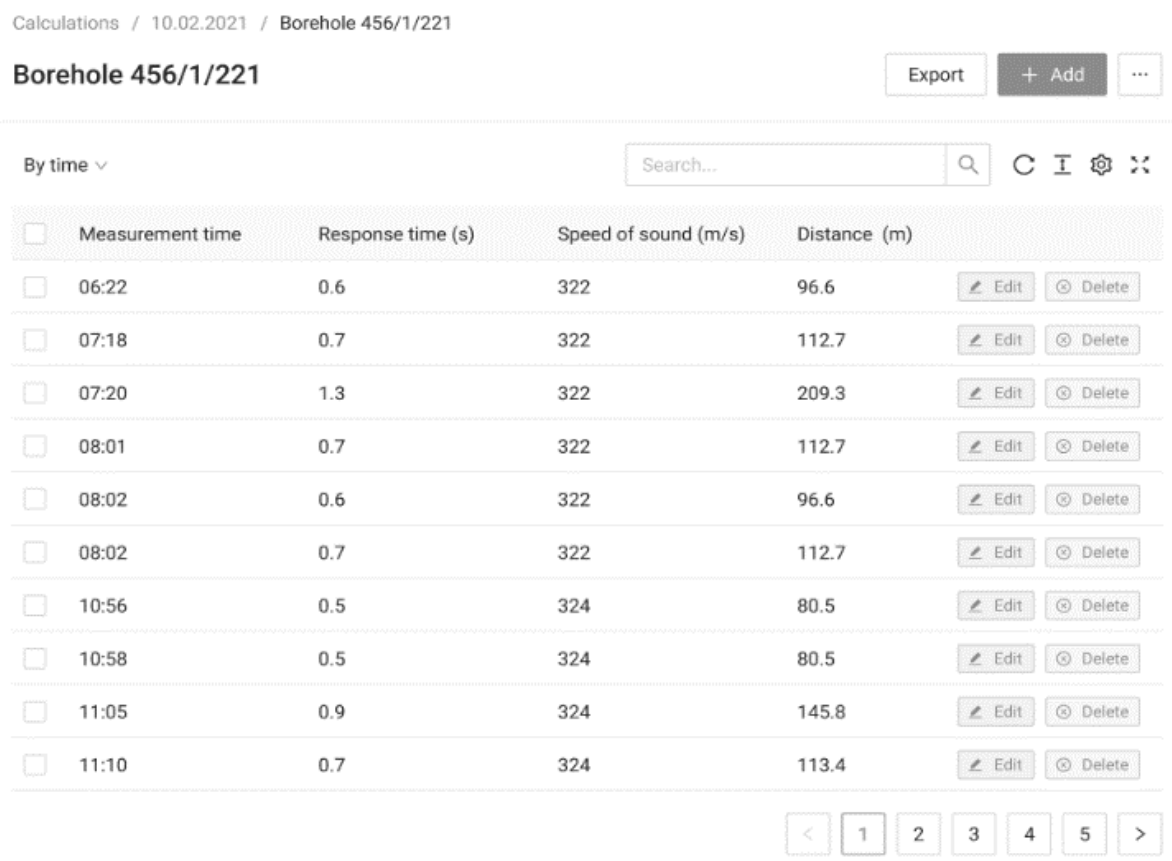

Fig. 4. Program interface for data export/import.

\begin{tabular}{l} 
Data editing \\
Measurement time \\
\hline $06: 10$ \\
Response time $(\mathrm{s})$ \\
\hline 0.6 \\
\hline Speed of sound $(\mathrm{m} / \mathrm{s})$ \\
\hline 322 \\
\hline
\end{tabular}

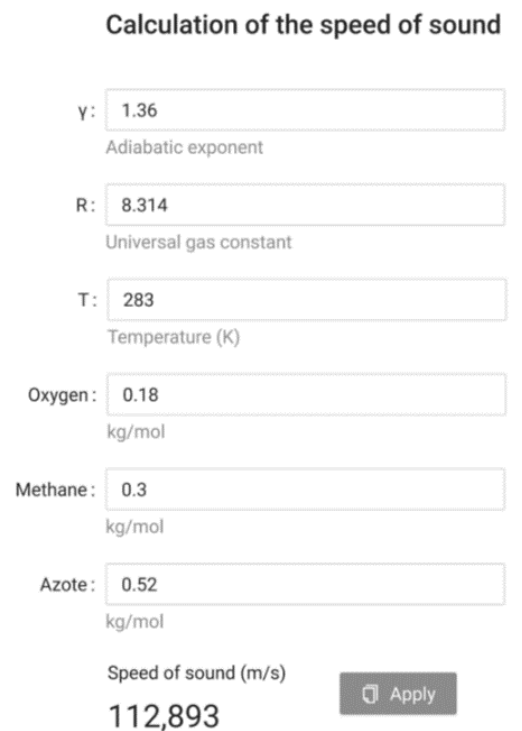

Fig. 5. The interface of the program module for editing the obtained results. 
The results of boreholes extent processed with software are shown in Table 2.

Table 2. Results of boreholes extent processed with software.

\begin{tabular}{|c|c|c|c|c|c|c|c|}
\hline 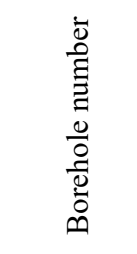 & 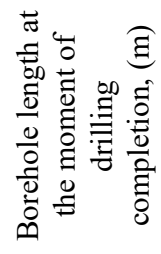 & 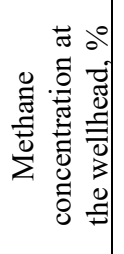 & 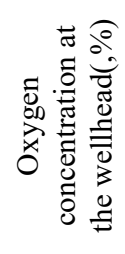 & 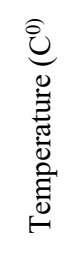 & 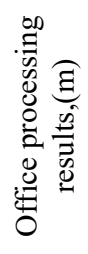 & 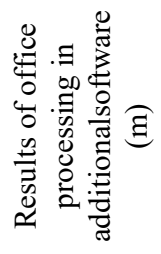 & 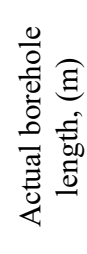 \\
\hline $\begin{array}{c}\text { Borehole } \\
\text { №1 }\end{array}$ & 150 & 1.98 & 20.32 & 23 & 103 & 111 & 110 \\
\hline $\begin{array}{l}\text { Borehole } \\
\text { №2 }\end{array}$ & 150 & 20.51 & 16.31 & 23 & 81 & 87 & 86 \\
\hline $\begin{array}{l}\text { Borehole } \\
\text { №3 }\end{array}$ & 150 & 1.58 & 20.48 & 23 & 80 & 83 & 83 \\
\hline $\begin{array}{c}\text { Borehole } \\
\text { №4 }\end{array}$ & 150 & 2.12 & 20.29 & 23 & 109 & 114 & 113 \\
\hline $\begin{array}{l}\text { Borehole } \\
\quad \text { №5 } \\
\end{array}$ & 150 & 33.26 & 13.84 & 23 & 122 & 136 & 135 \\
\hline $\begin{array}{c}\text { Borehole } \\
\text { a №6 }\end{array}$ & 150 & 34.11 & 12.54 & 23 & 102 & 116 & 115 \\
\hline $\begin{array}{l}\text { Borehole } \\
\quad \text { №7 } \\
\end{array}$ & 150 & 2.02 & 20.31 & 23 & 55 & 57 & 58 \\
\hline $\begin{array}{c}\text { Borehole } \\
\text { №8 }\end{array}$ & 150 & 44.39 & 11.43 & 23 & 134 & 140 & 141 \\
\hline $\begin{array}{c}\text { Borehole } \\
\text { №9 }\end{array}$ & 150 & 37.51 & $12, .88$ & 23 & 92 & 104 & 104 \\
\hline $\begin{array}{c}\text { Borehole } \\
\text { №10 }\end{array}$ & 150 & 2.55 & $20, .23$ & 23 & 70 & 74 & 75 \\
\hline
\end{tabular}

\section{Conclusion}

Measurements were carried out in 10 boreholes used for in seam degasification. In mine observations, it was found that their length varies from 57 to $140 \mathrm{~m}$. At the same time, the methane content at the wellheads varies within the range of $1.58-44.39 \%$. A decrease in the length of a borehole working section occurs due to its wells violation and water encroachment ofthe borehole. The developed software makes it possible to determine quickly the length of degasification boreholes with satisfactory accuracy. The research results can be used to monitor the technical condition of boreholes, to increase the efficiency of applied coal seams degasification technologies and to ensure the safety of miningworks. 


\section{References}

1. S.V. Slastunov, A.V. Ponizov, A.P. Sadov, A.M.-B. Khautiev, Mining Informational and Analytical Bulletin, 6, 15 (2020)

2. K. Sofiiskyi, O. Petukh, E3S Web of Conferences, 109, 00097 (2019)

3. S.V. Serdyukov, L.A. Rybalkin, T.V. Shylova, International Multidisciplinary Scientific GeoConference Surveying Geology and Mining Ecology Management, SGEM 19(1.3), 339 (2019)

4. A.V. Azarov, A.V. Patutin, 5th ISRM Young Scholars' Symposium on Rock Mechanics and International Symposium on Rock Engineering for Innovative Future, 944 (2019)

5. A. Patutin, S. Serdyukov, Procedia Engineering, 191, 287 (2017)

6. V. Demin, N. Nemova, T. Demina, Parameters determination of the sudden coal and gas outbursts preventing method, 141 (2014)

7. V.S. Zaburdyaev, Degassing parameters for high-performance working areas at the anexplored mine fields, 63 (2021)

8. V.R. Alabyev, V.D. Ashihmin, O.V. Plaksienko, R.A. Tishin, Prospects for industrial methane production in the mine n.A. V.M. Bazhanov using vertical surface wells, 3 (2020)

9. V.S. Zaburdayev, Effect of coal gas petrographic composition on gas recovery in the wells, 14 (2019)

10. V.S. Brigida, Yu.V. Dmitrak, O.Z. Gabaraev, V.I. Golik, Use of destressing drilling to ensure safety of donbass gas-bearing coal seams extraction, 7 (2019) 